\title{
Toxicity of Spores of Clostridium botulinum Strain 33 A in Irradiated Ground Beef
}

\author{
By E. FERNANDEZ, T. TANG AND N. GRECZ \\ Biology Department, Illinois Institute of Technology, Chicago, Illinois 60616
}

(Accepted for publication 2I November 1968)

\begin{abstract}
SUMMARY
Sterilizing doses of $\gamma$-radiation for food products (4.5 Mrad.) do not completely inactivate spore toxin or enzymes. The present study concerns spore toxin during and after irradiation of $4 \times 10^{6}$ spores of Clostridium botulinum per $\mathrm{g}$. of canned ground beef irradiated to $4.5 \mathrm{Mrad}$., at temperatures of $-25^{\circ}, 0^{\circ}$ and $+25^{\circ}$. During subsequent incubation of irradiated samples at $30^{\circ}$ for 10 months, periodic analyses showed no viable spores. Toxin was tested on (i) non-homogenized samples and (ii) samples homogenized in a tissue grinder.

In samples irradiated at $-25^{\circ}$ and $0^{\circ}$ and in un-irradiated un-incubated controls, 4 minimal lethal doses (m.l.d.) of toxin were found in non-homogenized samples immediately after irradiation. The toxin titre of irradiated samples gradually diminished to approximately half of its initial value at the end of Io months at $30^{\circ}$. In identical sets of homogenized irradiated samples, 8 m.l.d. were found initially and the titre increased to $44 \mathrm{~m}$.l.d. after 2 weeks to 4 months of incubation at $30^{\circ}$. Thereafter, the toxin titre slowly deteriorated to approximately $25 \mathrm{~m}$.l.d. at the end of $\mathrm{I} 0$ months.

Samples irradiated at $25^{\circ}$ exhibited a definite increase in toxin titre even immediately after irradiation. This seems to suggest the possibility of new toxin synthesis either during or after radiation. The toxin titre in homogenized samples reached $64 \mathrm{~m}$.1.d. after 2 months at $30^{\circ}$ and thereafter slowly diminished to $3 \mathrm{I}$ m.l.d. at Io months.

Toxin titres in radiation-damaged spores were small in comparison to un-irradiated $C$. botulinum growing in beef which reached 1000 to 5000 m.l.d. in 2 days at $30^{\circ}$.
\end{abstract}

\section{INTRODUCTION}

The work described in this paper is based upon two main observations:

(a) Spores of Clostridium botulinum type A contain some active toxin which is highly resistant to heat (Grecz \& Lin, I966; Grecz et al. 1967; Lin, I966).

(b) Spores which have been killed by $\gamma$-radiation (3.6 to $5.0 \mathrm{Mrad}$.) still contain active toxin (Kempe \& Graikoski, 1962; Grecz \& Lin, 1966). These findings indicate that the essential molecule(s) responsible for radiation survival of spores is considerably more sensitive to radiation than is spore toxin.

Cellular death from ionizing radiation is directly related to lesions in the nuclear DNA (Howard-Flanders, 1961; Szybalski \& Lorkiewicz, 1962; Ginoza, I967; Read, 1968). However, concurrently, radiation causes some inactivation of other components such as botulinum toxin (Wagenaar \& Dack, I960; Skulberg, 1965; Grecz \& Lin, I966; Grecz et al. 1967), enzymes, etc. The amount of damage to enzymes is not known.

It has been demonstrated that radiation-damaged spores placed into a nutrient 
medium are still able to perform limited metabolic activity, e.g. they can germinate and grow into an abortive vegetative cell (Rowley, Feeherry \& El-Bisi, I968). Apparently sufficient enzymes remain active to carry out germinative processes and to synthesize new cell proteins, one of which may be botulinum toxin. In this connexion, it was of interest to study the possibility that radiation-damaged spores may be able to synthesize new toxin without showing any obvious signs of growth and multiplication. This question is of vital importance to food preservation programmes as well as to the basic understanding of metabolic capabilities of radiation-damaged spores.

\section{METHODS}

Spores of Clostridium botulinum strain 33A, a highly radiation-resistant strain, were incorporated into ground beef and sealed in thermal-death time (t.d.t.) cans. Approximately $4 \times 10^{6}$ spores of $C$. botulinum $33 \mathrm{~A}$ were inoculated per $\mathrm{g}$. of ground beef. The spores were initially heat-shocked at $80^{\circ}$ for $10 \mathrm{~min}$. in order to destroy all heatsensitive 'vegetative' toxin and to activate spores for germination. The samples were irradiated with Co-6o to $4.5 \mathrm{Mrad}$. at a dose rate of $0.3 \mathrm{Mrad} / \mathrm{hr}$. The temperatures during irradiation was controlled at $-25^{\circ}, 0^{\circ}$ and $+25^{\circ}$. It required approximately I $5 \mathrm{hr}$ to irradiate to $4.5 \mathrm{Mrad}$. Thus spores irradiated at $+25^{\circ}$ had ample opportunity for germination and perhaps for some limited development, whereas at $-25^{\circ}$ and $0^{\circ}$ metabolic changes were arrested. After irradiation the cans were incubated at $30^{\circ}$ and representative samples were withdrawn for examination at regular time intervals up to Io months. The experimental outline is presented in Table I. A total number of

\section{Table I. Experimental outline}

$\begin{array}{cc}\begin{array}{c}\text { Temp. during } \\ \text { irradiation }\end{array} & \begin{array}{c}\text { Total no. } \\ \text { cans }\end{array} \\ 25^{\circ} & 28 \\ 0^{\circ} & 28 \\ -25^{\circ} & 28\end{array}$

\begin{tabular}{|c|c|c|c|c|c|c|c|}
\hline 0 & I wk. & 2 wk. & $4 \mathrm{wk}$ & $2 \mathrm{mo}$ & $4 \mathrm{mo}$ & $6 \mathrm{mo}$. & Io mo. \\
\hline 3 & 5 & 5 & 3 & 3 & 3 & 3 & 3 \\
\hline 3 & 5 & 5 & 3 & 3 & 3 & 3 & 3 \\
\hline 3 & 5 & 5 & 3 & 3 & 3 & 3 & 3 \\
\hline
\end{tabular}

Inoculum: $4 \times 10^{8}$ spores of $C$. botulinum per g. of ground beef.

28 cans was irradiated at each temperature. The number of cans examined at each time interval is indicated in Table I. Viable counts were performed either by colony counts or by the most probable number method (Fisher \& Yates, 1953) using Wynne broth (Wynne, Schmieding \& Daye, 1955) or Wynne broth plus $1.5 \%$ agar as the recovery medium. Details of methods were described by Grecz, Snyder et al. (1965).

The amount of toxin in the samples was assayed by intraperitoneal injection of 0.2 to $\mathrm{I} \cdot 0 \mathrm{ml}$. of appropriate dilutions into two (I 8 to $2 \mathrm{I}$ g.) white mice. Death of at least one of the animals within 4 days was considered a presumptive positive reaction; the test was confirmed with two unprotected and two protected mice, using specific type A antitoxin. The results were expressed as minimal lethal doses (m.l.d.) by the method of Wagenaar \& Dack (I960), taking into account the dilution of sample and the volume injected. For example, assume that $0.4 \mathrm{ml}$. of $\mathrm{I} / 8$ dilution caused death but $0.2 \mathrm{ml}$. of $\mathrm{I} / 8 \mathrm{had}$ no effect, or $\mathrm{I} / 20(4 / \mathrm{IO} \times \mathrm{I} / 8=\mathrm{I} / 20)$ was toxic but $\mathrm{I} / 40$ was not. Hence the sample contained $20 \mathrm{~m} .1$.d. but not $40 \mathrm{~m}$.l.d. 
The beef samples were prepared by two methods for injection into mice:

Method $r$. About I $\mathrm{g}$. of beef was diluted I/2, I/4, I/8, and so on. The meat particles were then allowed to settle and the supernatant was drawn up into a syringe and injected intraperitoneally.

Method 2. The beef samples were homogenized in a tissue grinder and appropriate dilutions were made so that homogenized beef tissue was injected with the liquid into the mouse. This was thought to be necessary because botulinum toxin is known to be absorbed on food particles (Grecz \& Dack, 1963).

\section{Table 2. Initial toxicity of un-irradiated samples}

Initial spore inoculum: $4 \times 10^{6}$ spores of $C$. botulinum 33A. Initial toxicity: 4 m.l.d.

\begin{tabular}{lccc} 
Control & \multicolumn{2}{c}{ Toxicity (m.l.d.) } & \\
sample & $\begin{array}{c}\text { Non- } \\
\text { homogenized }\end{array}$ & $\begin{array}{c}\text { Homogenized } \\
\text { beef }\end{array}$ & Spore count \\
I & $2 \cdot 7$ & 8 & $2 \cdot 0 \times 10^{6}$ \\
2 & 4 & 8 & $5 \cdot 81 \times 10^{6}$ \\
3 & 2 & 8 & $3.47 \times 10^{6}$ \\
Average & $2 \cdot 9$ & 8 & $3.76 \times 10^{6}$
\end{tabular}

Table 3. Toxicity of samples irradiated to $4.5 \mathrm{Mrad}$. at $-25^{\circ}$

\begin{tabular}{|c|c|c|}
\hline \multirow{2}{*}{$\begin{array}{c}\text { Time of } \\
\text { incubation } \\
\text { at } 30^{\circ}\end{array}$} & \multicolumn{2}{|c|}{$\begin{array}{l}\text { Average toxicity of triplicate } \\
\text { samples (m.l.d.) }\end{array}$} \\
\hline & Non-homogenized & Homogenized beef \\
\hline 0 & $4 \cdot 0$ & $8 \cdot 0$ \\
\hline I week & $4 \cdot 0$ & $28 \cdot 4$ \\
\hline 2 weeks & $3 \cdot 6$ & $44 \cdot 4$ \\
\hline I month & 3.6 & $37 \cdot 3$ \\
\hline 2 months & $3 \cdot 0$ & $35 \cdot 5$ \\
\hline 4 months & $2 \cdot 9$ & $36 \cdot 0$ \\
\hline 6 months & $2 \cdot 7$ & $32 \cdot 0$ \\
\hline Io months & $2 \cdot 7$ & $26 \cdot 6$ \\
\hline
\end{tabular}

RESULTS

Un-irradiated samples. The beef samples were initially inoculated with $4 \times 10^{6} \mathrm{spores} / \mathrm{g}$. containing 4 m.l.d. of spore toxin as tested in the stock suspension of spores in phosphate buffer. After incorporation into ground beef $94 \%$ of the spores could be detected by the most probable number method (Table 2). Furthermore, approximately $3 / 4$ of the initial amount of spore toxin could be recovered from non-homogenized samples, homogenized beef showed twice as much toxin as would be expected from intact spores.

Irradiated samples. After irradiation to $4.5 \mathrm{Mrad}$., the beef samples contained no detectable viable organisms either immediately at the start of incubation or after incubation at $30^{\circ}$ for up to Io months. This indicated that $4.5 \mathrm{Mrad}$. was an effective sterilizing dose and that there was no detectable repair of initial radiation damage after irradiation.

During incubation at $30^{\circ}$ the changes in toxin titre were different depending on sample treatment during irradiation, namely; whether the samples were irradiated at $-25^{\circ}, 0^{\circ}$ or $+25^{\circ}$. 
Samples irradiated at $-25^{\circ}$. The initial toxin titre in samples $\gamma$-irradiated to 4.5 Mrad. at $-25^{\circ}$ did not decrease to a detectable degree compared with unirradiated controls (Table 3 ). Here the homogenized sample contained $8 \mathrm{~m} .1 . d$. and non-homogenized 4 m.l.d. of toxin. On incubation at $30^{\circ}$ non-homogenized samples did not show any detectable increase in toxicity, whereas, homogenized samples increased to 28 m.l.d. after I week and to more than $40 \mathrm{~m}$.l.d. after 2 weeks at $30^{\circ}$. On incubation beyond 2 weeks, there appeared to be a very definite tendency for slow toxin deterioration, perhaps analogous to toxin decline in stored cheese (Grecz, Wagenaar \& Dack, 1965).

Table 4. Toxicity of samples irradiated to 4.5 Mrad. at $0^{\circ}$

$\begin{array}{lcc}\begin{array}{c}\text { Time of } \\ \text { incubation } \\ \text { at } 30^{\circ}\end{array} & \text { Non-homogenized } & \begin{array}{c}\text { Average toxicity of triplicate } \\ \text { samples (m.l.d.) }\end{array} \\ \text { o } & 4 \cdot 0 & 8 \cdot 0 \\ \text { I week } & 3 \cdot 1 & 10 \cdot 7 \\ 2 \text { weeks } & 5 \cdot 3 & 28 \cdot 4 \\ \text { I month } & 3 \cdot 6 & 34 \cdot 7 \\ 2 \text { months } & 3 \cdot 3 & 40 \cdot 0 \\ 4 \text { months } & 2 \cdot 8 & 44.4 \\ 6 \text { months } & 2 \cdot 0 & 40 \cdot 0 \\ \text { Io months } & 2 \cdot 0 & 24 \cdot 0\end{array}$

Table 5. Toxicity of samples irradiated to $4.5 \mathrm{Mrad}$. at $+25^{\circ}$

Time of
incubation
at $30^{\circ}$
I week
2 weeks
1 month
2 months
4 months
6 months
10 months

Average toxicity of triplicate

$\begin{array}{cc}\text { Non-homogenized } & \text { Homogenized beef } \\ 8.0 & 21 \cdot 3 \\ 3.6 & 34.7 \\ 2.7 & 52.4 \\ 2.4 & 52.4 \\ 2.7 & 64.0 \\ 2.0 & 53.3 \\ 2.7 & 53.3 \\ 1.6 & 30.8\end{array}$

Samples irradiated at $0^{\circ}$. The toxicity of samples irradiated at $0^{\circ}$ to $4.5 \mathrm{Mrad}$ (Table 4) was about the same as that shown in Table 3. Furthermore, the amount of toxin detected during incubation of these two sets of samples was practically identical. This seems to suggest that the samples irradiated at non-physiological temperatures, i.e. at $0^{\circ}$ and $-25^{\circ}$ behaved in a similar manner after and during incubation.

Samples irradiated at $+25^{\circ}$ to $4.5 \mathrm{Mrad}$. The samples behaved distinctly differently than those irradiated at $-25^{\circ}$ and $0^{\circ}$ (Table 5).

Here it can be seen that the initial sample, before incubation contained 8 m.l.d. in the non-homogenized and $21 \mathrm{~m} .1$.d. in the homogenized beef, i.e. 2-3 times as much toxin as in those samples irradiated at $-25^{\circ}$ and $0^{\circ}$. The data seem to indicate that toxin synthesis was initiated during irradiation at $+25^{\circ}$. As already mentioned, the time during irradiation was $\mathrm{I} 5 \mathrm{hr}$ i.e. sufficient for appreciable physiological activity. On incubation at $30^{\circ}$ the toxin titre in homogenized samples after I week rose to almost 35 m.l.d., after 2 weeks to $52 \mathrm{~m} .1 . d$. and after 2 months to $64 \mathrm{~m} .1$.d. Thereafter the 
toxin titre appeared to diminish slowly to a final $31 \mathrm{~m} .1 . \mathrm{d}$. after Io months. It can be seen that the peak toxin titre in these samples was considerably higher than the amount of toxin in Tables 3 and 4. Therefore, it may be suspected that new toxin, as well as new spore enzymes, may have been synthesized during irradiation of spores at $+25^{\circ}$. These enzymes were perhaps capable of synthesizing the additional quantity of toxin shown in Table 5, as compared with samples irradiated at non-physiological temperatures. However, this increase in toxin titre is open to other interpretations than enzymic synthesis.

The final toxin titre after 10 weeks at $30^{\circ}$ was practically the same in all three experiments, namely 27 m.l.d. (Table 3), 24 m.l.d. (Table 4), and 31 m.l.d. (Table 5).

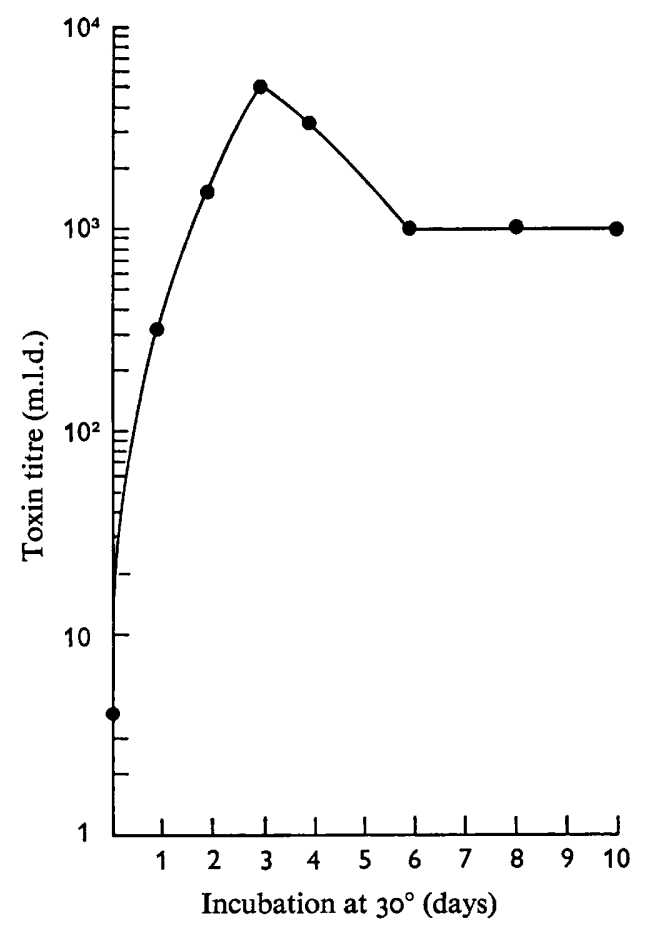

Fig. I. Toxin production in lean ground beef by Clostridium botulinum $33 \mathrm{~A}$ during incubation at $30^{\circ}$.

In contrast to homogenized samples, the toxin titre in non-homogenized beef: (i) showed a much lower titre in all cases, (ii) never increased on incubation, and (iii) slowly but consistently diminished starting from the beginning of the experiment.

Synthesis of toxin in ground beef. For purposes of comparison, ground beef was inoculated with $4 \times 10^{6}$ spores per g. and the organisms were allowed to develop at $30^{\circ}$ (Fig. I). A peak toxin titre of 5000 m.l.d. was reached within 3 days after which the titre dropped to 1000 m.l.d. The titre remained at 1000 m.l.d. for up to Io days, which was the duration of the experiment.

From these data it can be concluded that the toxin titre developed by un-irradiated Clostridium botulinum in ground beef was approximately Ioo-fold higher than the peak titre developed by radiation-damaged spores. 


\section{DISCUSSION}

Evidence is presented to show that although beef can be effectively sterilized by $\gamma$-radiation, existing spores may in some way introduce a significant degree of toxicity which is not necessarily detectable immediately after irradiation, but becomes evident only after 2 to 4 weeks of incubation at $30^{\circ}$. The cause of this increase in toxin titre is not clear. Several possibilities may be considered including: (i) new toxin synthesis by those spore enzymes which remain active after irradiation, (ii) germination of irradiated spores, (iii) slow lysis of spores at $30^{\circ}$, (iv) activation or fragmentation of pre-existing toxin molecules, etc.

It remains a puzzle why the progressive increase in toxin titre during storage at $30^{\circ}$ could be detected only after homogenization of the sample, but not in unhomogenized beef. It is unlikely that the tissue homogenizer would accomplish any significant degree of spore breakage even if the radiation-damaged spores germinated and possibly grew out into vegetative forms. On the other hand, spore breakage in itself may not necessarily explain the observed increase in toxicity. Unfortunately no microscopic observations could be made in the present study because of the relatively low spore inoculum and because of interference by beef particles.

It should be emphasized that the practical significance of spore toxicity for radiation sterilization of foods appears to be of negligible importance. The amount of toxin developed in radiation-damaged spores is relatively small compared with that synthesized by un-irradiated Clostridium botulinum growing in ground beef. Furthermore, under natural conditions, $C$. botulinum would not be expected to be present in large numbers. However, the problem is of definite theoretical interest. It is only too obvious that there remains much ignorance about spore toxin in C. botulinum and particularly about the possibility of physiological activity in radiation-damaged spores, such as potential de novo protein synthesis, which may have been suggested by the present experiments. Solution of these problems will require many more experiments as well as more defined experimental conditions than were used in the present work.

Work supported by U.S. Public Health Service Grant UI 00177 and PHS Career Development Award 5-K3-AI-2I, 763.

\section{REFERENCES}

Fisher, R. A. \& YATES, F. (1953). Statistical Tables for Biological Agricultural and Medical Research, 4th ed., p. 49. New York: Hafner Publishing Co.

GINOZA, W. (1967). The effect of ionizing radiations on nucleic acids of bacteriophages and bacterial cells. A. Rev. Microbiol. 2r, 325.

Grecz, N. \& DACK, G. M. (1963). Toxin production in naturally separated liquid and solid components in preparations of heated surface ripened cheese inoculated with Clostridium botulinum. J. Food Sci. 28, 276.

Grecz, N. \& Lin, C. A. (I966). Properties of heat resistant toxin in spores of Clostridium botulinum 33 A. 'Symposium on Botulism'. IX International Congress of Microbiology, Moscow, $20-22$ July i966.

Grecz, N., WAGENAAR, R. O. \& DACK, G. M. (1965). Storage stability of Clostridium botulinum toxin and spores in processed cheese. Appl. Microbiol. 13, IOI4.

Grecz, N., SNYder, O. P., Walker, A. A. \& ANellis, A. (1965). Effect of temperature of liquid nitrogen on radiation resistance of spores of Clostrodium botulinum. Appl. Microbiol. 13, 527. 
Grecz, N., Lin, C. A., Tang, T., So, W. L. \& Sehgal, L. R. (1967). The nature of heat resistant toxin in spores of Clostridium botulinum. Japan J. Microbiol. Ir, 384.

HowARD-FLANDERS, P. (196I). Factors affecting radiation injury to DNA in bacteria and bacteriophage systems. Brookhaven Symp. Biol. 14 , I8.

Kempe, L. L. \& Graikoski, J. T. (I962). Gamma ray sterilization and residual toxicity studies of ground beef inoculated with spores of Clostridium botulinum. Appl. Microbiol. ro, 3I.

LIN, C. A. (1966). Heat resistant toxin in spores of Clostridium botulinum. M.S. thesis. Illinois Institute of Technology, Chicago, Illinois.

READ, J. (1968). Repair by cells of damage caused by radiations or by radiomimetic chemicals. In Actions Chemiques et Biologique des Radiations. Ed. by M. Haissinsky. Paris: Masson et Cie.

Rowley, D. B., Feeherry, F. \& El-Bisi, H. M. (1968). Effect of sodium chloride and irradiation on the germination and outgrowth of spores of Clostridium botulinum 62 A. Bact. Proc. G. 96.

Skulberg, A. (1965). The resistance of Clostridium botulinum type E toxin to radiation. J. appl. Bact. 28, 139.

SZYBALSKI, W. \& LoRkIEWICZ, Z. (1962). On the nature of the principal target of lethal and mutagenic radiation effects. Abh. dt. Akad. Wiss. Berl. Med. no. I, 63.

WAgENAAR, R. O. \& DACK, G. M. (1960). Studies on the inactivation of type A Clostridium botulinum toxin by irradiation with cobalt-6o. Fd Res. 25, 279.

Wynne, E. S., Schmieding, W. R. \& Daye, G. T., Jun. (I955). A simplified medium for counting Clostridium botulinum spores. Fd Res. $20,9$. 